\title{
Lost and Found in (Self-)Translation: From Colonial to Post-colonial Contexts
}

\author{
Denise Merkle, Université de Moncton \\ Gillian Lane-Mercier, Université McGill \\ Michel Mallet, Université de Moncton
}

Those in an unequal linguistic and cultural power relationship, whether they be a colonized or a migrating people, frequently risk getting lost in translation. On the one hand, colonized groups include the Indigenous peoples of Africa, the Americas and Australia, for example, but also those colonized by an invader such as the Bohemians by Austro-Hungarians, the French by the British in Canada and the Irish by the British, or by a centralizing government, such as the French government's "colonization" of speakers of dialects and patois in the aftermath of the French Revolution. On the other hand, as a result in large part of global warming and conflict that is often a corollary of overpopulation, migration flows (from South and Central America to North America and from Africa to Europe, for example) are on the increase. What fundamentally distinguishes, yet paradoxically links, colonized and migrating peoples is choice: the former, while still on their land, are forcibly subjected to the domination of the invader, whereas the latter choose - to the degree that conflict in their home country gives them a choice-to leave their country and often their destination, though-hence the paradox-invasion may be what motivates them to migrate.

Colonized peoples are generally expected to adopt the language, cultural values and religious practices of the colonizer through a process of gradual or violent assimilation. A rare exception in the history of imperialist colonization is the Mongolian, in particular the Khan family's, approach, which was (relatively) tolerant of the cultural and religious practices of conquered peoples (Vietze 2017). More usual, though, is the gradual assimilation of the languages and cultures of the conquered people through a lack of institutional support which encourages participatory self-translation, although more violent approaches can range from prohibiting the use of a conquered people's language and religion through legislation to taking children from their families and sending the former to residential schools where they are forced not only to adopt the colonizer-or settler in the Canadian context-lifestyle, as the Canadian and US governments have done to Indigenous peoples, but also to self-translate. What are perceived to be incompatible lifeworlds (Tyulenev 2014) by the dominant language and culture are simply not tolerated, and efforts are consciously deployed to assimilate difference. The violence of extreme manifestations of these acts could not be semiotically translated more poignantly than by Kent Monkman in his 2016 painting The Scream that depicts Indigenous children being literally torn from their families by the Canadian government represented by the RCMP in Red Serge and traditionally attired Catholic clergy and nuns. In Canada and the US Indigenous languages were banned; the speaking of English (or French in Québec) was required, Indigenous children's traditional 
long hair cut short, and the adopting of settler customs and clothing imposed (see Adams 1995; Giago 2006 for US context; see Legacy of Hope Foundation 2001 for Canadian context).

Some colonized peoples succumb to the pressures and passively assimilate through selftranslation, some are traumatized to the point of identitary loss so profound that they are unable to function productively in society, since "generations of a people raised in abuse, and without parents [residential school survivors], can hardly be expected to build healthy communities" (Whyte 2017), whereas others adopt various forms of resistance through, on the one hand, political activism, which this special issue does not specifically address, or, on the other hand, artistic, linguistic and literary activism that may include translation, which it does address.

Take, for example, Monkman, who himself says of his work that it "is somehow related to or inspired by my Native heritage and the place that I sit between two cultures because I'm of mixed blood [Swampy Cree father; English/Irish Canadian mother], so I think I've always been trying to define that place in between to some degree..." (Monkman qtd. in Art Saskatchewan 2018). He does not refer to himself as a translated person, and he does not appear to be in any way lost. Rather his sense of self is asserted in the "place in between" as is his non-binary two-spirit alter-ego, Miss Chief Eagle Testickle (a pun of mischief egotistical). He is, in fact, consciously "availing himself of the language of a settler culture and in that language he's telling different stories about settler-Indigenous relations" (Fischer qtd. in Everett-Green 2017). Monkman's unique cultural positioning has enabled him to uncover what the settler culture has hidden (Hall 1959) through his innovative interpretations of settler-Indigenous relations. "I pillage the history of painting, from the Baroque era to Romanticism, to investigate and challenge the subjectivity of the European eye on Aboriginal peoples and the 'New World'," says Monkman (qtd. in Loft and Dickenson 2012) of his paintings inspired by the Old Masters, including Miss America (2012). The artist re-evaluates visual representations of Indigenous and non-Indigenous peoples in Western art to teach settlers more about how their dominant cultural system has worked to alienate Indigenous peoples from their own languages and cultures by foreignizing them.

His paintings can be considered the visual art equivalent of minor literature. Monkman is painting minor cultures into the major Western artistic tradition by "recontextualiz[ing] Old Master conventions" (Everett-Green) as well as deconstructing, for example, Picasso's cubism. His response to the exclusion of the Indigenous perspective in the Western tradition, specifically in the settler paintings of George Caitlin and Paul Kane, includes Miss Chief Eagle Testickle telling the story of colonization from an Indigenous point of view. In the same vein, an Old Master who has inspired more than one of Monkman's paintings is Giovanni Battista Tiepolo, whose "Europe," one of his Apollo and The Four Continents (1751-3), motivated Miss Europe (2016), reproduced on the cover of this issue. In his painting, Tiepolo represented Europe as the culmination of Enlightened political, social and cultural development, whereas Indigenous peoples in the Americas ("America'), Africa and even Europe were depicted as less civilized, even tribal, cultures. By contrast, Monkman appropriates elements of Tiepolo's composition, and then turns the tables by recasting so-called "Enlightened" 
Europeans from an amalgam of time periods and backgrounds as perpetrators of chaotic excess, wanton violence and simplistic stereotypes. They may have spread Christianity, what they consider to be the best of European culture, an appetite for incessant progress, and a taste for unrestrained luxury to the "New World," but also intolerance, greed and destruction. Monkman's far less flattering representation of European civilization and what it exported to "America" (Tiepolo)/Miss America introduces settlers to an alternative, non-Western interpretation of history. In addition to creating a minor painting tradition, Monkman performs intersemiotic translation in The Prayer Language (2001), a "series of paintings [in which he] transcribe[s] Cree syllabic translations of Christian hymns into multiple layers of semi-transparent acrylic paint” (Monkman qtd. in Art Saskatchewan).

Alternatively, Indigenous writers may have other types of innovative relationships with translation in and through their works. On the one hand, after many years of self-translation into the settler language, a writer may revert to his maternal tongue. Tomson Highway spoke only Cree and Dene until age 6, and at 56 started writing in Cree, the "source language" of his earlier works, as he explains: "the characters speak in Cree in his [Highway's] head but the words often come out in English or French" (Highway 2010). In 2008, he wrote the libretto for an opera in his native language, The Journey (Pimooteewin), "a musical adaptation of a First Nations myth about the trickster's visit to the land of the dead" (Charlebois and Nothof 2016), and, in 2010, produced the Cree originals of the plays The Rez. Sisters and Dry Lips Oughta Move to Kapuskasing. Fitzhenry and Whiteside expressed interest in releasing in Cree the plays that had been performed in English since the 1980s. According to Highway, "the Cree versions [...] are actually the original versions. As it turns out, the $[. .$.$] ones that$ came out 20 years ago were the translation [...]. The language that I'm most familiar with - that I'm closest to, emotionally and otherwise-is Cree, which is my native tongue ... It's the first language that I spoke. My parents and my oldest brothers and sisters didn't even speak English" (Highway). In addition, he translated his libretto for The (Post) Mistress (2011) into French and Cree.

On the other hand, a poet, such as Joséphine Bacon, may refuse to (self-)translate, opting, rather, for concurrent writing in her maternal language (Innu) and in the settler language (in her case French), to which at least three of her publications attest: Quelque part/Uiesh (2018); Un thé dans la toundra/Nipishapui nete mushuat (2013); Bâtons à message/Tshissinuatshitakana (2009). Bacon limits her translation activities to those that serve a sociolinguistic function by translating and performing voice overs for documentaries and short films, in addition to teaching the Innu language and translating from that language into French (Joséphine Bacon 2018).

Three Indigenous creators, three resistance activities: creating a minor art form in the major tradition; writing in translation followed by (re-)writing in the mother tongue; refusing to translate in the creative domain, while reserving translation to projects that will contribute to the sociolinguistic vitality of her mother tongue. Through these activities, all three creators make visible or voice their identitary difference.

Of course, the term "minor literature," which we have appropriated and applied to the field of the visual arts when discussing Kent Monkman's work, was first proposed by Gilles Deleuze and 
Félix Guattari (2003 for the English translation) to recognize the originality of Franz Kafka's literary creations. Kafka constructed unique linguistic realities through his creative writing and developed a writing machine (Deleuze and Guattari 28) that involved making multilingualism resound within his own major vehicular language, which was German. As a German-speaking Jew living in Czechspeaking Prague under Habsburg rule, Kafka, a multilingual member of a minority group, spoke a local variety of German and was, according to Deleuze and Guattari (26), interested in making a minor utilization of a major language a possibility. He made intensive use of the vernacular language-the Prague variety of German, his maternal or territorial language - to disrupt the major language and in so doing the official and institutional functions it represented. However, the minor language had no desire "to assume a major function in language, to offer its service as a sort of state language, an official language” (Deleuze and Guattari 16). Rather, Kafka's carefully crafted major language became minor through his literary writing that made "use of the polylingualism of [his] own [oppressed] language, [...] a minor or intensive use of it" (Deleuze and Guattari 49-50). In minor literature the major language is decoded because the major language has denied validity to the minority. Kafka made use of the referential language of Jewish cultural reterritorialization (23), Yiddish, and the mythic language of religion, Hebrew (25). High German was, of course, the vehicular language of administration and government-The Castle (Kafka 1998) — that had to be deterritorialized (25). Kafka's independently innovative response to language and cultural tensions was revolutionary.

By contrast, the creation of what can be considered a minoritizing literature may be accidental, perhaps even involuntary. Anglo-Jewish writer Israel Zangwill, born in Victorian London to a PolishLatvian immigrant family, did not spend his early years in the East End Jewish ghetto, where poor immigrants tended to first settle. Yet, as a child he spoke Yiddish, learned Hebrew, and attended the Jews' Free School from the age of eight like other children of immigrant families. The school, run by Jews, was located in the ghetto and designed to assimilate children linguistically and culturally in order to integrate them into British society, without, however, compromising the Jewish religion. At university, Zangwill also learned French. He considered Yiddish the national language of the Jewish diaspora, even if, in the early 1890s it was considered a Jewish-German dialect. As an adult, he mastered Hebrew well enough to become a competent, prolific and appreciated translator of Hebrew poetry into English. Zangwill sought, and achieved, validation from his host country; as a writer, he was well integrated into English cultural and literary circles, while wishing to be recognized as Jewish. In the early 1890s, the Jewish Publication Society of America commissioned, for American and British Jews, Children of the Ghetto: A Study of a Peculiar People (1998). The novel became "the first [British] Anglo-Jewish best-seller" (Rochelson "Introduction" 11) to expose the spiritual crisis facing the Anglicized Jewish community, which resulted from a profound sense of loss: loss of a feeling of belonging, loss of a traditional life considered authentic that was dying, loss of clear and strict rules of behaviour (14). Zangwill belonged to this minority group who wished to be recognized as full members of their adopted country, yet profoundly regretted having to give up an essential part of their identity in the process. 
Even though self-translated by Zangwill, linguistic multilingualism is still clearly present in the novel, and various linguistic clues communicate the source language to the reader; for example, Hebrew, the language of scripture, is written in formal English ("Peace be to you."), whereas the vernacular Yiddish is tinged with archaisms, often "sounding" unnatural ("I am looking for work. Peradventure have you something for me?”) (Zangwill 96-97). Zangwill's exploration of these marginalized languages is anything but fluent. Immigrants self-translate, feel torn between two or more languages, cultures and identities, speak an English that tends to be calqued on Yiddish with modified pronunciation, e.g. "ve English valk about in all vedders" (99), and code-switching between English and Yiddish sometimes marks conversations. Not only self-translation but translation also clearly plays a large role in the novel; a case in point, ghetto youngsters learn to read Hebrew by sight translation of Hebrew texts into Yiddish.

The Yiddish structures and vocabulary in the novel were designed to introduce Anglo-Saxons and assimilated Jews to this foreign culture and language that was in their city. Nevertheless, Zangwill's attitude to Yiddish, a minority stigmatized language, "the most hopelessly corrupt and hybrid jargon ever evolved" (Zangwill 94), that was dying out at the end of the nineteenth century, was ambivalent as a result of his position as an Anglo-Jewish writer. Translating the minor language in his fiction reflected the ambivalent attitude shared by many of his Jewish readers who criticized the codemixing and codeswitching of Yiddish-speaking immigrants. As an accomplished writer, Zangwill refused to make intensive use of the minor language in this novel and his short stories (in contrast to some of his theatre plays) in the wake of the negative critical reception with which Motso Kleis was met, yet, ironically perhaps, his works contributed to the revival of Yiddish in the twentieth century. Nonetheless, writing in nonstandard English underlined Zangwill's alterity, as did wishing for his Jewishness to be recognized and respected, thereby (inadvertently?) asserting a position of "foreignness" while seeking recognition as "one of them [his English peers]" (Rochelson "Language" 400). Less ambiguously, the characters who populate his novel, the majority of whom are bilingual, if not multilingual to varying degrees, are newcomers attempting to use a major language with varying degrees of success. Secular conversations are multilingual in the Jewish ghetto, whereas in middleclass Kensington, where successful, i.e. assimilated, Jews live, traditions have been reinvented and Londonian modernity adopted, often at the expense of ethnic identity and personal integrity (Falk 82). We nonetheless contend that the implicit multilingualism of the novel, which, intentionally or not, resounds in the major language, makes of this novel a minor incursion into major literature.

The (self-)translators, whether they be Indigenous or migrants, studied in this issue are also bilingual or multilingual foreigners within a major language, or in the process of reclaiming a formerly repressed language. Over the past centuries, global cultural and linguistic diversity has been lost through the "devaluing and eradication of countless languages" (Merkle and Lane-Mercier 5) as a consequence of "the implementation of legal, educational, and cultural policies that have required the use of a single national-cum-official language in the public domain" (5), if not in the private domain as well. Homogenization efforts included suppressing maternal languages and cultures to the point of making them illegal. In reaction, Indigenous groups in particular, but (im)migrant communities as well, 
are party to nationalist, regional and identitary demands for recognition, which may find expression through reclaiming their maternal languages by means of creative writing and translating activities. As members of multilingual and multicultural groups, they refuse to accept democracies founded on "the institutionalized refusal to acknowledge difference-whether cultural, linguistic, ethnic, religious or other" (5). They are subverting the more or less coercive implicit and explicit hierarchies that attempt to enforce their assimilation, marginalization, and exclusion. In so doing, they are making the effort to become minor by "making the plurilingualism within their own [major] language resound" (Deleuze and Guattari 26). As we have seen above, in reaction to centuries of settler appropriation of their culture through ethnographic or literary translation (Cardinal "Xhuyaa et Ts'ehk'i," "Why do they do it?," "Cross Purposes"), Indigenous groups now resort to strategies that can range from creating minor visual art forms to writing in the original language after years of self-translation as well as concurrent writing in the maternal and settler language. However, the cases examined in this issue are not limited to strategies retained by Indigenous writers and (self-)translators; in addition, the potential contribution of settler and colonizer translators to legitimizing Indigenous voices is explored, as are migrant voyages in and through (self-)translation.

This special issue brings together new research on Indigenous (self-)translation strategies retained by Cree writer and translator Tomson Highway (Marie Leconte) along with Inuit poets (e.g. Taqralik Partridge and Alootook Ipellie) and filmmakers, such as Zacharias Kunuk and the Nunavut Animation Lab (Karine Bertrand), "settler" or dominant culture translation strategies retained for translating Canadian Innu militant poet Natasha Kanapé Fontaine (Lianne Moyes) and for translating American Native fiction into minoritized Iberian Spanish (Isis Herrero López). These contributions deal implicitly and explicitly with the ideological position of the translating subject (Tymoczko 2003) with respect to the source text and the culture that produced it. In addition, a contribution by Manuel Meune explores how the translation of Lucky Luke comics - the theme of which is European contact with Amerindians - into Francoprovençal, a marginalized Indigenous European vernacular language, can contribute to the revitalization of this language and culture. Finally, the concluding article investigates the impact of migration, from Beijing to London and back, on identity construction and the central role that cultural and linguistic translation plays in the process (Wangtaolue Guo). The changing dynamics - from loss to gain, and from gain to loss-in translational writing are examined through a detailed analysis of Xiaolu Guo's A Concise Chinese-English Dictionary for Lovers. All of the contributions nuance the linguistic, cultural and identitary tribulations to which colonized and migratory peoples are subjected, the double-edged sword of (self-)translation, and the paradoxical gains that can be found in the sometimes painful process of self-translation. 


\section{REFERENCES}

Adams, David Wallace. Education for Extinction: American Indians and the Boarding School Experience, 1875 1928. University Press of Kansas, 1995.

Cardinal, Philippe. "Xhuyaa et Ts'ehk'i : les traductions de deux versions des hauts faits du corbeau et l'éthique de la traduction des récits traditionnels des Premières Nations." TTR, vol. 17, no. 2, 2004, pp. 131-41.

. "Why Do They Do It ?-A Brief Inquiry into the Real Motives of Some of the Participants in the Recording, Transcribing, Translating, Editing, and Publishing of Aboriginal Oral Narrative." TTR, vol. 18, no. 2, 2005, pp. 135-59.

. "Cross-Purposes: Translating and Publishing Traditional First Nations Narratives in Canada at the Turn of the Millennium." Translation Effects. The Shaping of Modern Canadian Culture, edited by Kathy Mezei, Sherry Simon and Luise von Flotow, McGill Queen's University Press, 2014, pp. 271-89.

Charlebois, Gaetan, and Anne Nothof. "Tomson Highway." Canadian Theatre Encyclopedia. 2016. http://www.canadiantheatre.com/dict.pl?term=Highway\%2C\%20Tomson. Accessed 4 August 2018.

Deleuze, Gilles, and Félix Guattari. Kafka: Toward a minor literature. Translated by Dana Polan, University of Minnesota Press, 2003.

Everett-Green, Robert. "Kent Monkman: A trickster with a cause crashes Canada's 150th birthday party." The Globe and Mail, published 6 January 2017, revised 12 November 2017. https://www.theglobeandmail.com/news/national/canada-150/kent-monkman-shame-andprejudice/article33515775/. Accessed 3 August 2018.

Falk, Liliane. "The Use of Immigrant Dialect in Israel Zangwill's Children of the Ghetto." In Papers from the 21st Annual Meeting of the Atlantic Provinces Linguistic Association, edited by M.-L. Tarpent, Mount Saint Vincent University, Halifax, Nova Scotia, Canada, 7-8 November 1997, vol. 21, 1998, pp. 80-88.

Giago, Tim A. Children Left Behind: Dark Legacy of Indian Mission Boarding Schools. Clear Light, 2006.

Hall, Edward T. The Silent Language. Doubleday, 1959.

Highway, Tomson. "Tomson Highway releases plays in Cree.” CBC News Ottawa, 8 November 2010. cbc.ca/news/canada/ottawa/tomson-highway-releases-plays-in-cree-1.895683?ref=rss. Accessed 4 August 2018.

"Joséphine Bacon." Mémoire d'encrier. 2018. http://memoiredencrier.com/josephine-bacon/. Accessed 4 August 2018. 
Kafka, Franz. The Castle. Translated and with a preface by Mark Harman. Schocken, 1998.

Legacy of Hope Foundation. Where are the Children? Healing the Legacy of the Residential Schools. 2001. http://wherearethechildren.ca/en/about/. Accessed 9 August 2018.

Loft, Steve and Rachelle Dickenson. "Kent Monkman: English" In Centre Space. 2012. http://www.centre-space.ca/archives/kent-monkman-miss-america/kent-monkmanenglish/. Accessed 2 September 2018.

Merkle, Denise, and Gillian Lane-Mercier. "Introduction. Toward an Ethics of Diversity." In Minority Languages, Majority Languages and Official Language Policies, edited by Gillian Lane-Mercier, Jane Koustas and Denise Merkle, McGill Queen's University Press, 2018, 3-32.

Monkman, Kent. “Artist Statement for The Prayer Language.” In Art Saskatchewan: Kent Monkman. 2018. http://www.artsask.ca/en/artists/kentmonkman. Accessed 3 August 2018.

Rochelson, Meri-Jane. "Language, Gender, and Ethnic Anxiety in Israel Zangwill's Children of the Ghetto." English Literature in Transition, 1880-1920, vol. 31, no. 4, 1988, pp. 399-412.

-. "Introduction." In Children of the Ghetto: A Study of a Peculiar People by Israel Zangwill. Wayne State University Press, 1998, pp. 11-44.

Tyulenev, Sergey. Translation and Society. Routledge, 2014.

Tymoczko, Maria, «Ideology and the Position of the Translator: In What Sense is a Translator 'In Between'? » In Apropos of Ideology - Translation Studies on Ideology - Ideologies in Translation Studies, edited by María Calzada Pérez. St Jerome, 2003, p. 181-201.

Vietze, Andrew. The Mongols Kublai Khan: Emperor of China. The Rosen Publishing Group, 2017.

Whyte, Murray. "Kent Monkman fills in the blanks in Canadian history." The Star. 27 January 2017. https://www.google.ca/search?ei=Eq5kW7ezLMiS0wLInoioDw\&q=Monkman+U+of+T+ exhibit + The + Star\&oq $=$ Monkman $+\mathrm{U}+$ of $+\mathrm{T}+$ exhibit + The + Star\&gs $\quad 1=$ psyab.3...3152.8428.0.8709.22.22.0.0.0.0.240.3108.0j17j2.19.0...0...1c.1.64.psyab..3.0.0...0.w7fWV cyug48. Accessed 3 August 2018.

Zangwill, Israel. Children of the Ghetto: A Study of a Peculiar People. Wayne State University Press, 1998. 